
\title{
$\begin{array}{ll}\text { Research Square } & \begin{array}{l}\text { Preprints are preliminary reports that have not undergone peer review. } \\ \text { They should not be considered conclusive, used to inform clinical practice, } \\ \text { or referenced by the media as validated information. }\end{array}\end{array}$
}

\section{Dosimetric Parameters Associated with the Long-Term Oncologic Outcomes of Gamma Knife Surgery for Sellar and Parasellar Tumors in Pediatric Patients}

\author{
Eun Jung Lee \\ Seoul National University Hospital Department of Neurosurgery \\ Ji Yeoun Lee \\ Seoul National University Hospital Department of Neurosurgery \\ Jin-Wook Kim \\ Seoul National University Hospital Department of Neurosurgery \\ Ji-Hoon Phi \\ Seoul National University Hospital Department of Neurosurgery \\ Yong Hwy Kim ( $\nabla$ kimyh96@snu.ac.kr) \\ Seoul National University Hospital https://orcid.org/0000-0001-9009-4191

\section{Seung-Ki Kim} \\ Seoul National University Hospital Department of Neurosurgery

\section{Hyun-Tai Chung} \\ Seoul National University Hospital Department of Neurosurgery

\section{Kyu-Chang Wang} \\ National Cancer Center, Neuro-oncology clinic

\section{Dong Gyu Kim} \\ Seoul National University Hospital Department of Neurosurgery
}

\section{Research Article}

Keywords: Radiosurgey, dosimetry, children, sellar, brain tumor

Posted Date: May 10th, 2021

DOI: https://doi.org/10.21203/rs.3.rs-495870/v1

License: (c) (i) This work is licensed under a Creative Commons Attribution 4.0 International License. Read Full License 


\section{Abstract \\ Purpose}

We aimed to investigate the dosimetric parameter and the minimally required dose associated with long-term control of sellar and parasellar tumors after gamma knife surgery (GKS) in children.

\section{Methods}

A retrospective analysis was performed on pediatric patients under the age of 19 who were diagnosed with sellar and parasellar tumors and received GKS in our institution from 1998 to 2019. Cox proportional hazards regression analyses were used to investigate the dosimetric parameters associated with treatment outcome. The Kaplan-Meier method was used to analyze tumor control rates after GKS.

\section{Results}

Thirty-seven patients with 40 sellar and parasellar tumors, including 22 craniopharyngiomas and 12 pituitary adenomas, were followed up for a mean of 85.8 months. The gross target volume was $0.05-15.28 \mathrm{~cm}^{3}$, and the mean marginal dose was 15.8 Gy (range, 9.6-30.0 Gy). Ten patients experienced treatment failure at 28.0 \pm 26.7 months. The actuarial 5- and 10-year tumor control rates were $79.0 \%$ and $69.8 \%$, respectively. $\mathrm{D}_{98 \%}$ was an independent predictive factor of tumor control ( $p=0.007$, hazard ratio $0.846,95 \%$ confidence interval $0.749-0.956)$, with cutoff values of $11.5 \mathrm{~Gy}$ in the entire cohort and $10 \mathrm{~Gy}$ in the craniopharyngioma group. Visual deterioration occurred in two patients with the maximum point dose of $10.1 \mathrm{~Gy}$ and $10.6 \mathrm{~Gy}$ to the optic apparatus.

\section{Conclusion}

$D_{98 \%}$ is a reliable index of the minimum required dose for long-term control of sellar and parasellar tumors after GKS. The optimal $D_{98 \%}$ value for each diagnosis needs to be elucidated in the future.

\section{Introduction}

The radical resection of tumors arising in the sellar and parasellar regions without endocrine or neurological morbidities is often a challenge for neurosurgeons, even with the various surgical approaches because of their intimate anatomical relationship with the surrounding critical neurovascular structures including the hypothalamus, optic apparatus, pituitary stalk and gland, cavernous sinus, and internal carotid artery [1-3]. Moreover, sellar and parasellar tumors such as craniopharyngiomas (CRPs) and pituitary adenomas (PA) tend to exhibit aggressive behavior and invade nearby structures and thus are prone to recur [4]. In these cases, revisional transsphenoidal or transcranial surgery on residual or recurrent tumors in this region is usually arduous and leads to a higher risk of morbidities [5]. Stereotactic radiosurgery (SRS) has been established as a safe and effective alternative to open surgery or conventional radiotherapy in the adult population. It delivers a precise high dose of ionizing radiation to a well-defined target. A steep radiation dose fall-off at the margin of the target in SRS spares the surrounding neural tissues from the harmful effect of radiation [6]. Recent advances in SRS hypofractionation systems have reduced the risk of radiation-induced optic neuropathy (RION), contributing to the expansion of SRS application to tumors in these regions [7]. However, the long-term efficacy and safety of SRS for sellar and parasellar tumors in children have not been clearly elucidated. Moreover, as fractionated SRS is difficult to adopt in uncooperative children, tumors near the optic apparatus are often irradiated with a de-escalated 
dose in a single fraction in the concerns of RION, which can lead to lower tumor control rates. Therefore, given the lifelong impact of both tumor control and visual function on pediatric patients, we aimed to investigate the dosimetric parameter associated with tumor control and the minimally required dose for long-term SRS efficacy while preserving visual function.

\section{Patients And Methods}

\section{Patient population}

A retrospective analysis was performed on pediatric patients under the age of 19 who were diagnosed with sellar and parasellar tumors and received Gamma knife surgery (GKS) in our institution from 1998 to 2019. A total of 48 GKS procedures were performed in 41 patients for sellar and parasellar tumors, and 40 GKS procedures performed in 37 patients were analyzed in this study, excluding cases of second GKS for treatment failure and those with a short followup period of less than 6 months. The study was approved by the institutional review board (IRB No. 2011-182-1177). Informed consent was waived due to the retrospective nature of the study.

\section{Clinical evaluations}

Neuro-ophthalmologic evaluations, including Goldmann or Humphrey perimetry, were performed in all patients before GKS, 6 months and 1 year after GKS, and then biannually. Approximately half of the patients $(n=21,53 \%)$ had visual impairment before GKS. Endocrinological assessment was performed in all patients before GKS and every 6 months after GKS by measuring the levels of hormones, including growth hormone, insulin-like growth factor-l, adrenocorticotropic hormone, serum cortisol, free T4, thyroid-stimulating hormone, luteinizing hormone, folliclestimulating hormone, estradiol or total testosterone, and prolactin using radioimmunoassay and immunoradiometric assay, in venous blood samples collected between $8 \mathrm{AM}$ and $10 \mathrm{AM}$.

\section{Protocol and strategies of Gamma knife radiosurgery}

The details of the GKS technique used in this pediatric population did not differ from those in adults [8]. However, patients $\leq 13$ years old underwent GKS under general anesthesia, and those $>13$ years old underwent GKS under local anesthesia considering the children's safety. A rigid stereotactic frame was applied for single-fraction GKS, and a thermoplastic mask has been applied for fractionated GKS since the Gamma Knife ${ }^{\circledR}$ Icon ${ }^{T M}$ was introduced in March 2016. The gross target volume (GTV) was represented by contrast-enhancing lesions on MR images. We did not add a margin for expansion from the GTV to the planning tumor volume. In principle, we planned to deliver no more than $8 \mathrm{~Gy}$ of radiation to the optic apparatus, even at the risk of delivering lower radiation to the tumor.

\section{Tumor control and dosimetric parameters}

Tumor control was evaluated by MR images 6 months after GKS and annually thereafter. Treatment failure was defined as an increment in volume by $20 \%$ from the baseline. Data were extracted from GammaPlan ${ }^{\circledR}$ software using the dosevolume histogram for the following dosimetric parameters: GTV, planned volume, treated target volume (TTV), marginal dose, isodose line, coverage, Paddick conformity index, $D_{\min }, D_{98 \%}$ (the minimum dose received by $98 \%$ of the GTV), $D_{\text {mean }}, D_{2 \%}$ (the maximum dose received by $2 \%$ of the GTV), and $D_{\max }$. In cases with fractionated GKS, the single-fraction

doses equivalent to the multifractionation schemes regarding the marginal dose, $D_{\text {min }}, D_{\text {mean }}, D_{\text {max }}, D_{98 \%}$, and $D_{2 \%}$, were estimated in these patients using the linear-quadratic model of cell survival from radiation with the formula: BED = $\operatorname{nd}(1+d /[a / \beta])$, where $d=$ dose per fraction $(G y), n=$ number of fractions, $n d=$ total dose $(G y)$, and $a / \beta=$ tissue repair capacity (Gy) [9]. 
All statistical analyses were performed using SAS statistical software (SAS system for Windows, version 9.4; SAS institute, Cary, NC), and a $p$ value $<0.05$ was considered to be significant. Differences in continuous variables were analyzed using the Mann-Whitney U-test, while the chi-square test and Fisher's exact test were used for categorical variables. Univariate and multivariate Cox proportional hazards regression analyses were used to investigate the factors associated with treatment outcome. The multivariate analysis included only the factors considered clinically relevant among the variables that were significant at the level of $p$ value of 0.20 in the univariate analysis. Stepwise selection was performed using $p<.05$ for entry and $p>0.10$ for removal. The Kaplan-Meier method was used to analyze tumor control after GKS.

\section{Results}

\section{Patients}

The mean age at GKS was 14.5 years old (range, 5-25), and the mean follow-up period after 40 GKS was 85.8 months (range, 11-195 months, Table 1). CRP was the most common $(n=22,55 \%)$, followed by PA $(n=12,30 \%)$, mesenchymal chordoma or chondrosarcoma $(n=3)$, pilocytic astrocytoma $(n=2)$, and anaplastic astrocytoma $(n=1)($ Table 2$)$. In PAs, six patients had functioning tumors: 2 with Cushing's disease, 2 with acromegaly, and 2 with prolactinoma. Before GKS, radiation therapy was performed in 7 patients and chemotherapy was performed in 1 .

All patients except four showed hormonal deficiencies before GKS, namely, panhypopituitarism in $65.0 \%$ and partial deficiency in $35.0 \%$. No patient experienced newly developed hypopituitarism after GKS.

In most patients, the visual outcome of GKS was favorable, with no change (75\%) or an improvement in vision (20\%) reported. However, visual deterioration occurred in two patients after GKS without tumor progression. One patient received a marginal dose of 19.0 Gy for acromegaly, and another patient was treated with a marginal dose of $16.0 \mathrm{~Gy}$ for CRP. The maximum point doses to the optic apparatus of the two patients were $10.1 \mathrm{~Gy}$ and $10.6 \mathrm{~Gy}$, respectively.

\section{Tumor control and dosimetric parameters}

The GTV ranged from 0.05 to $15.28 \mathrm{~cm}^{3}$ with a mean value of $2.67 \mathrm{~cm}^{3}$. The shortest distance between the tumor and the optic nerve was $3.1 \mathrm{~mm}$ on average, with six tumors abutting, another six displacing, and one encasing the optic nerve. Seven tumors (5 CRPs and 2 PAs) were treated with fractionated GKS, with three fractions delivered to six tumors and five fractions delivered to one. The $\alpha / \beta$ ratio for these two kinds of tumors was assumed to be 3 . The marginal dose was prescribed with a mean value of $15.8 \mathrm{~Gy}$ (range, $9.6-30.0 \mathrm{~Gy}$ ) at $50 \%$ isodose line in all tumors except four. Ten patients (25\%) experienced treatment failure at $28.0 \pm 26.7$ months (range, 1-82): 7 of 22 CRPs, 2 of 12 PAs, and 1 anaplastic astrocytoma. Reoperations were performed in five patients, GKS was repeated in two, and radiotherapy was performed in one. Two were lost to follow-up. In six functioning PAs, none reached endocrinological remission by GKS. The dosimetry of the groups with treatment success and failure are compared in Figure 1.

In the univariate analysis, GTV-TTV $(p=0.016)$, coverage $(\%)(p=0.016), \mathrm{D}_{\min }(p=0.017)$, and $\mathrm{D}_{98 \%}(p=0.007)$ were statistically significant factors associated with treatment outcome. In the multivariate analysis, $D_{98 \%}$ was an independent predictive factor of tumor control ( $p=0.007$, hazard ratio $0.846,95 \%$ confidence interval $0.749-0.956$, Table 3$)$. Using the receiver operating characteristic (ROC) curve, the cutoff value of $D_{98 \%}$ for predicting GKS tumor control was determined to be $11.5 \mathrm{~Gy}$, eliciting $80 \%$ sensitivity and $68 \%$ specificity (ROC area $=0.784,95 \%$ confidence interval $0.635-$ $0.932)$. $\mathrm{D}_{98 \%} \geq 11.5 \mathrm{~Gy}$ significantly reduced the risk of treatment failure by 6.19 times $(95 \%$ confidential interval, $\mathrm{Cl}$, $1.31-29.21, p=0.021)$ in comparison with $D_{98 \%}<11.5 \mathrm{~Gy}$. The overall actuarial 5 - and 10-year tumor control rates were 
$79.0 \%$ and $69.8 \%$, respectively; however, there were significant differences in tumor control rates between the groups with $\mathrm{D}_{98 \%} \geq$ and $<11.5 \mathrm{~Gy}(95.2 \%$ and $87.3 \%$ versus $56.3 \%$ and $46.9 \%, p=0.008$, Figure 2$)$.

The results of Cox proportional hazard regression analysis in the CRP cohort are presented in Supplemental Table 1. The actuarial 5- and 10-year CRP control rates were 76.8\% and 59.8\%, respectively. Univariate and multivariate analyses showed that $D_{98 \%}$ was a statistically significant factor associated with tumor control $(p=0.024$, hazard ratio $0.843,95 \%$ confidence interval $0.727-0.977$ ). The 5 - and 10-year tumor control rates in the subgroups with $D_{98 \%} \geq 10$ Gy versus < 10 Gy were $93.3 \%$ and $61.3 \%$, respectively, versus $33.3 \%$ and $33.3 \%$, respectively (log-rank, $p=0.045$ ) (Figure 3 ). There was no difference in the tumor control rate depending on the component nature of CRP among solid, cystic, and mixed tumors (5-year tumor control rates: $80 \%$ versus $66.7 \%$ versus $76.2 \%$, log-rank, $p=0.324$ )

\section{Discussion}

\section{Oncologic outcomes of GKS on sellar and parasellar tumors}

Childhood-onset CRPs are prone to recur even after radical resection because of their invasive growth and adhesion to adjacent structures, although the histological diagnosis is benign $[10,11]$. Reoperation is often challenging, particularly in pediatric patients, and pose an increased risk of morbidities. SRS has been established as a safe and effective alternative treatment to surgery for residual or recurrent tumors. The proximity of the optic apparatus to the CRP leads to concerns over RION and compels operators to prescribe a lower radiation dose, resulting in a lower tumor control rate. A large cases series of GKS performed on 98 CRPs showed that a mean marginal dose of 11.5 Gy resulted in 5- and 10year local control rates of 60.8 and $53.8 \%$, respectively [12]. The present study revealed 5 - and 10 -year tumor control rates of $76.8 \%$ and $59.8 \%$, respectively, with a mean marginal dose of $15.3 \mathrm{~Gy}$. The optimal marginal dose and the decisive dosimetric parameters for the long-term control of CRPs remain unclear. Notably, $\mathrm{D}_{98 \%}$, rather than the marginal dose, was significantly associated with long-term tumor control, with a value of $\geq 10$ Gy resulting in 5 - and 10-year tumor control rates of $93.3 \%$ and $61.3 \%$, respectively. At times, some portion of the tumor is excluded from the prescription isodose line when planning due to safety concerns, more frequently in the sellar and parasellar tumors located near the organ at risk. In such cases, the prescription dose does not reflect the dose irradiated to the tumor site excluded from the prescription isodose line at all. On the other hand, $D_{98 \%}$ is the minimum dose received by $98 \%$ of the tumor volume, informing the actual lowest dose irradiated to the tumor, which is not simply deduced from the prescription dose or tumor coverage (\%). Our results indicate that tumor control closely correlates with the suboptimal doses delivered to some of the tumor cells rather than the sufficient dose most of the tumor cells receive. From this point of view, we suggest $D_{98 \%}$ as a valid indicator of the Maginot Line radiation dose necessary for tumor control, and we recommend $D_{98 \%} \geq 10 \mathrm{~Gy}$ for long-term tumor control of CRPs.

Meanwhile, SRS efficacy has been reported to depend on the properties of the tumor [1,13]. With a median marginal dose of $13 \mathrm{~Gy}$ (range, 9-20), the 5-year local control rates for solid versus mixed CRPs were reported to be $91.6 \%$ versus $68 \%$, respectively [13]. In contrast, the nature of the tumor, whether solid or cystic, was not statistically associated with tumor control in this study. The discrepancy in the results might be based on the differences in the nature of the tumor, size of the tumor, and radiation dose; however, large-scale studies exploring the GKS efficacy for CRPs in children are required in the future.

PAs account for less than 3\% of all pediatric intracranial tumors and show a higher incidence of functional tumors than adults $[14,15]$. The goals of SRS for functioning PAs are to restrain tumor growth, and promote endocrinological remission, so a higher dose is recommended than that for nonfunctioning PA (NFPA) $[5,16]$. In general, greater biochemical control was achieved in patients with Cushing's disease and acromegaly than in those with prolactinomas [5]. Marginal dose of 25 Gy was reported to play a critical role in the endocrinological remission rate: 52\% (range, 25- 
$70 \%)$ versus $63.5 \%$ (35-83\%) in Cushing's disease; 49\% (17-82\%) versus 40\% (17-65\%) in acromegaly; and $26 \%$ (23$27 \%$ ) versus $37 \%(18-50 \%)$ in prolactinoma [17-30]. Meanwhile, the optimal marginal dose for the local control of NFPA remains controversial. A multicenter study reported that a median marginal dose of 16 Gy resulted in 5- and 10-year tumor control rates of $95 \%$ and $85 \%$, respectively [31]. A recent meta-analysis reported that with a median dose of $15 \mathrm{~Gy}$, the 5- and 10-year random effects local tumor control rates after SRS were estimated to be $94 \%$ and $83 \%$, respectively [32]. However, it seems that favorable tumor control may be achievable with a marginal dose of only $12 \mathrm{~Gy}$, yielding a $95 \%$ control rate $[33,34]$.

In the present study, among the patients with functioning PAs, one patient with Cushing's disease who received $12.5 \mathrm{~Gy}$ and one patient with acromegaly who received 18.3 Gy experienced tumor progression despite undergoing GKS. None achieved endocrine remission, which was ascribable to an insufficient dose (mean, 19.6 Gy) delivered to the tumors in most patients due to the proximity of the optic apparatus. On the other hand, all NFPA cases were stationary after GKS with a marginal dose of $14 \mathrm{~Gy}$ during the 96 -months follow-up. As NFPA itself is not life-threatening, we recommend prescribing the minimum dose effective to arrest tumor growth while preserving hormone function.

\section{Visual outcome of GKS in patients with sellar and parasellar tumors}

The anterior visual pathway is believed to be one of the structures most vulnerable to radiation [2]. Traditionally, the tolerable dose to prevent RION is less than 8 Gy delivered to the optic apparatus [35, 36]. However, excessive constraints on the dose to the optic apparatus may limit the prescription of a sufficient marginal dose to the tumor or lead to less coverage of the target, which is associated with poor tumor control. Therefore, careful attention to treatment planning, considering both RION risk and long-term tumor control, is required. The risk of RION has been reported to range from 0 to $3 \%$ for maximum doses to the optic apparatus of less than 8-10 Gy [36-38]. Some authors have asserted that a maximum dose of $12 \mathrm{~Gy}$ is safe, although a dose $>12 \mathrm{~Gy}$ has been associated with RION [37, 38]. However, in the present study, post-GKS visual deterioration occurred in two patients who received maximum point doses to the optic apparatus of $10.1 \mathrm{~Gy}$ and $10.6 \mathrm{~Gy}$, respectively. Therefore, we recommend keeping a conservative cutoff value for the maximum point dose to the optic apparatus to avoid RION.

Achievement of long-term tumor control with preservation of visual and hormonal functions is worth pursuing, particularly in pediatric patients. For sellar and parsellar tumors, the proximity of the tumor to the optic apparatus and pituitary gland often restricts the dose that can be delivered to the tumor due to safety concerns. It also compels physicians to exclude a portion of the tumor from the prescription dose, leaving some tumor cells to be irradiated with a dose that is below that prescribed. However, insufficiently irradiated tumor cells can lead to progression. Therefore, it is imperative to clarify the dose window, ranging from a minimally effective dose for tumor control to a maximally safe dose to prevent RION, and plan for the delivery of proper radiation within that window while thoroughly covering the entire tumor. Many authors have sought to elucidate the relationship between the marginal dose and tumor control rates; however, the clear-cut association between them has not been statistically proven. We anticipate that this could be caused by discrepancies between the marginal dose and the actual dose delivered to the tumor cells. In this study, we revealed that $D_{98 \%}$ is significantly associated with tumor control rather than the marginal dose. $D_{98 \%}$ represents the actual minimum dose irradiated to the tumors in the volume, and thus, it may be a reliable index of the minimum required dose for long-term tumor control. There may still be a dose gradient between the $D_{98 \%}$ value for long-term tumor control and the tolerable maximum point dose to the optic apparatus. The tumors apart $>2 \mathrm{~mm}$ from the optic apparatus usually meet the required dose gradient due to the steep dose fall-off of GKS at the margin of the target; otherwise, fractionated radiosurgery may help lower the dose gradient [7]. These results are based on data derived from heterogeneous tumors with different biological behaviors, as well as a small sample size for each tumor type. Therefore, the relevant dosimetric factors and the optimal $D_{98 \%}$ value for long-term tumor control for each kind of pathology need to be elucidated by prospective, large-scale studies in the future. 


\section{Declarations}

\section{Funding}

This study is supported by a grant (No. 0520200030 to Kim YH) from Seoul National University Hospital.

\section{Conflicts of interest}

The following authors have no financial disclosures to declare: Eun Jung Lee, Ji Yeoun Lee, Jin-Wook Kim, Ji Hoon Phi, Yong Hwy Kim, Seung-Ki Kim, Hyun-Tai Chung, Kyu-Chang Wang, Dong Gyu Kim

Availability of data and material: The study was performed based on the electronic medical record, PACS, and GammaPlan ${ }^{\circledR}$ data of our institution. All data and materials as well as software application support our claims and comply with field standards.

\section{Code availability: Not applicable}

\section{Authors' contributions}

\begin{tabular}{|c|c|c|c|}
\hline Author & ORCID & e-mail & Contributions \\
\hline $\begin{array}{l}\text { Eun } \\
\text { Jung } \\
\text { Lee }\end{array}$ & & eunjlee21@gmail.com & $\begin{array}{l}\text { Writing - original draft, Data curation, Formal analysis, } \\
\text { Methodology, Visualization, Writing - review \& editing }\end{array}$ \\
\hline $\begin{array}{l}\text { Ji } \\
\text { Yeoun } \\
\text { Lee }\end{array}$ & & femiddang@gmail.com & Writing - review \& editing \\
\hline $\begin{array}{l}\text { Jin- } \\
\text { Wook } \\
\text { Kim }\end{array}$ & & wook616@hanmail.net & Data curation \\
\hline $\begin{array}{l}\text { Yong } \\
\text { Hwy } \\
\text { Kim }\end{array}$ & $\begin{array}{l}0000-0001- \\
9009-4191\end{array}$ & kimyh96@snu.ac.kr & $\begin{array}{l}\text { Conceptualization, Data curation, Methodology, Visualization, } \\
\text { Project administration, Writing - review \& editing, Funding } \\
\text { acquisition }\end{array}$ \\
\hline $\begin{array}{l}\text { Ji Hoon } \\
\text { Phi }\end{array}$ & & phi.jihoon@gmail.com & Writing - review \& editing \\
\hline $\begin{array}{l}\text { Seung- } \\
\text { Ki Kim }\end{array}$ & & nsthomas@snu.ac.kr & Writing - review \& editing \\
\hline $\begin{array}{l}\text { Hyun- } \\
\text { Tai } \\
\text { Chung }\end{array}$ & & hyuntaic@gmail.com & Data curation \\
\hline $\begin{array}{l}\text { Kyu- } \\
\text { Chang } \\
\text { Wang }\end{array}$ & & kcwang@snu.ac.kr & Writing - review \& editing \\
\hline $\begin{array}{l}\text { Dong } \\
\text { Gyu Kim }\end{array}$ & & gknife@snu.ac.kr & Conceptualization, Writing - review \& editing \\
\hline
\end{tabular}

Ethics approval: Not applicable

Consent to participate: Not applicable

Consent for publication: Not applicable 


\section{Conclusion}

$D_{98 \%}$ is significantly associated with long-term control of sellar and parasellar tumors. The optimal values of $D_{98 \%}$ for each diagnosis need to be established.

\section{References}

1. Veeravagu A, Lee M, Jiang BW, Chang SD (2010) The role of radiosurgery in the treatment of craniopharyngiomas. Neurosurg Focus 28 doi:Artn E11 10.3171/2010.2.Focus09311

2. Minniti G, Osti MF, Niyazi M (2016) Target delineation and optimal radiosurgical dose for pituitary tumors. Radiat Oncol 11:135. doi:10.1186/s13014-016-0710-y

3. Martinez-Barbera JP, Andoniadou CL (2020) Biological Behaviour of Craniopharyngiomas. Neuroendocrinology 110:797-804. doi:10.1159/000506904

4. Belirgen M, Berrak SG, Ozdag H, Bozkurt SU, Eksioglu-Demiralp E, Ozek MM (2012) Biologic tumor behavior in pilocytic astrocytomas. Childs Nerv Syst 28:375-389. doi:10.1007/s00381-011-1676-6

5. Jagannathan J, Yen CP, Pouratian N, Laws ER, Sheehan JP (2009) Stereotactic radiosurgery for pituitary adenomas: a comprehensive review of indications, techniques and long-term results using the Gamma Knife. J Neurooncol 92:345-356. doi:10.1007/s11060-009-9832-5

6. Amichetti M, Amelio D, Minniti G (2012) Radiosurgery with photons or protons for benign and malignant tumours of the skull base: a review. Radiat Oncol 7:210. doi:10.1186/1748-717X-7-210

7. Lee EJ, Cho YH, Yoon K, Cho B, Park ES, Kim CJ, Roh SW (2017) Radiosurgical decompression for benign perioptic tumors causing compressive cranial neuropathies: a feasible alternative to microsurgery? J Neurooncol 131:73-81. doi:10.1007/s11060-016-2268-9

8. Dho YS, Kim YH, Kim JW, Park CK, Chung HT, Kim SK, Paek SH, Wang KC, Kim DG (2018) Optimal strategy of gamma knife radiosurgery for craniopharyngiomas. J Neurooncol 140:135-143. doi:10.1007/s11060-018-2943-0

9. Jones B, Dale RG, Finst P, Khaksar SJ (2000) Biological equivalent dose assessment of the consequences of hypofractionated radiotherapy. Int J Radiat Oncol Biol Phys 47:1379-1384. doi:10.1016/s0360-3016(00)00571-X

10. Lee EJ, Cho YH, Hong SH, Kim JH, Kim CJ (2015) Is the Complete Resection of Craniopharyngiomas in Adults Feasible Considering Both the Oncologic and Functional Outcomes? J Korean Neurosurg S 58:432-441. doi:10.3340/jkns.2015.58.5.432

11. Kim SK, Wang KC, Shin SH, Choe G, Chi JG, Cho BK (2001) Radical excision of pediatric craniopharyngioma: recurrence pattern and prognostic factors. Childs Nerv Syst 17:531-536. doi:10.1007/s003810100458 discussion 537

12. Kobayashi T (2009) Long-term results of gamma knife radiosurgery for 100 consecutive cases of craniopharyngioma and a treatment strategy. Prog Neurol Surg 22:63-76. doi:10.1159/000163383

13. Niranjan A, Kano H, Mathieu D, Kondziolka D, Flickinger JC, Lunsford LD (2010) Radiosurgery for craniopharyngioma. Int J Radiat Oncol Biol Phys 78:64-71. doi:10.1016/j.ijrobp.2009.07.1693

14. Pandey P, Ojha BK, Mahapatra AK (2005) Pediatric pituitary adenoma: a series of 42 patients. J Clin Neurosci 12:124-127. doi:10.1016/j.jocn.2004.10.003

15. Perry A, Graffeo CS, Marcellino C, Pollock BE, Wetjen NM, Meyer FB (2018) Pediatric Pituitary Adenoma: Case Series, Review of the Literature, and a Skull Base Treatment Paradigm. J Neurol Surg B Skull Base 79:91-114. doi:10.1055/s-0038-1625984

16. Steele CA, MacFarlane IA, Blair J, Cuthbertson DJ, Didi M, Mallucci C, Javadpour M, Daousi C (2010) Pituitary adenomas in childhood, adolescence and young adulthood: presentation, management, endocrine and metabolic 
outcomes. Eur J Endocrinol 163:515-522. doi:10.1530/EJE-10-0519

17. Kobayashi T (2009) Long-term results of stereotactic gamma knife radiosurgery for pituitary adenomas. Specific strategies for different types of adenoma. Prog Neurol Surg 22:77-95. doi:10.1159/000163384

18. Petit JH, Biller BM, Coen JJ, Swearingen B, Ancukiewicz M, Bussiere M, Chapman P, Klibanski A, Loeffler JS (2007) Proton stereotactic radiosurgery in management of persistent acromegaly. Endocr Pract 13:726-734.

doi:10.4158/EP.13.7.726

19. Hoybye C, Grenback E, Rahn T, Degerblad M, Thoren M, Hulting AL (2001) Adrenocorticotropic hormone-producing pituitary tumors: 12- to 22-year follow-up after treatment with stereotactic radiosurgery. Neurosurgery 49:284-291. doi:10.1097/00006123-200108000-00008 discussion $291-282$

20. Grant RA, Whicker M, Lleva R, Knisely JP, Inzucchi SE, Chiang VL (2014) Efficacy and safety of higher dose stereotactic radiosurgery for functional pituitary adenomas: a preliminary report. World Neurosurg 82:195-201. doi:10.1016/j.wneu.2013.01.127

21. Sheehan JP, Xu Z, Salvetti DJ, Schmitt PJ, Vance ML (2013) Results of gamma knife surgery for Cushing's disease. J Neurosurg 119:1486-1492. doi:10.3171/2013.7.JNS13217

22. Castinetti F, Taieb D, Kuhn JM, Chanson P, Tamura M, Jaquet P, Conte-Devolx B, Regis J, Dufour H, Brue T (2005) Outcome of gamma knife radiosurgery in 82 patients with acromegaly: correlation with initial hypersecretion. J Clin Endocrinol Metab 90:4483-4488. doi:10.1210/jc.2005-0311

23. Kobayashi T, Mori Y, Uchiyama Y, Kida Y, Fujitani S (2005) Long-term results of gamma knife surgery for growth hormone-producing pituitary adenoma: is the disease difficult to cure? J Neurosurg 102 Suppl:119-123. doi:10.3171/jns.2005.102.s_supplement.0119

24. Ronchi CL, Attanasio R, Verrua E, Cozzi R, Ferrante E, Loli P, Montefusco L, Motti E, Ferrari DI, Giugni E, Beck-Peccoz P, Arosio M (2009) Efficacy and tolerability of gamma knife radiosurgery in acromegaly: a 10-year follow-up study. Clin Endocrinol (Oxf) 71:846-852. doi:10.1111/j.1365-2265.2009.03589.x

25. Franzin A, Spatola G, Losa M, Picozzi P, Mortini P (2012) Results of gamma knife radiosurgery in acromegaly. Int J Endocrinol 2012: 342034 doi:10.1155/2012/342034

26. Lee CC, Vance ML, Xu Z, Yen CP, Schlesinger D, Dodson B, Sheehan J (2014) Stereotactic radiosurgery for acromegaly. J Clin Endocrinol Metab 99:1273-1281. doi:10.1210/jc.2013-3743

27. Wattson DA, Tanguturi SK, Spiegel DY, Niemierko A, Biller BM, Nachtigall LB, Bussiere MR, Swearingen B, Chapman $\mathrm{PH}$, Loeffler JS, Shih HA (2014) Outcomes of proton therapy for patients with functional pituitary adenomas. Int J Radiat Oncol Biol Phys 90:532-539. doi:10.1016/j.jirobp.2014.06.068

28. Jezkova J, Hana V, Krsek M, Weiss V, Vladyka V, Liscak R, Vymazal J, Pecen L, Marek J (2009) Use of the Leksell Gamma Knife in the Treatment of Prolactinoma Patients EDITORIAL COMMENT. Obstet Gynecol Surv 64:727-729

29. Tanaka S, Link MJ, Brown PD, Stafford SL, Young WF Jr, Pollock BE (2010) Gamma knife radiosurgery for patients with prolactin-secreting pituitary adenomas. World Neurosurg 74:147-152. doi:10.1016/j.wneu.2010.05.007

30. Cohen-Inbar O, Xu Z, Schlesinger D, Vance ML, Sheehan JP (2015) Gamma Knife radiosurgery for medically and surgically refractory prolactinomas: long-term results. Pituitary 18:820-830. doi:10.1007/s11102-015-0658-1

31. Sheehan JP, Starke RM, Mathieu D, Young B, Sneed PK, Chiang VL, Lee JY, Kano H, Park KJ, Niranjan A, Kondziolka D, Barnett GH, Rush S, Golfinos JG, Lunsford LD (2013) Gamma Knife radiosurgery for the management of nonfunctioning pituitary adenomas: a multicenter study. J Neurosurg 119:446-456. doi:10.3171/2013.3.JNS12766

32. Kotecha R, Sahgal A, Rubens M, De Salles A, Fariselli L, Pollock BE, Levivier M, Ma L, Paddick I, Regis J, Sheehan J, Yomo S, Suh JH (2020) Stereotactic radiosurgery for non-functioning pituitary adenomas: meta-analysis and International Stereotactic Radiosurgery Society practice opinion. Neuro Oncol 22:318-332.

doi:10.1093/neuonc/noz225

Page $9 / 16$ 
33. Mingione V, Yen CP, Vance ML, Steiner M, Sheehan J, Laws ER, Steiner L (2006) Gamma surgery in the treatment of nonsecretory pituitary macroadenoma. J Neurosurg 104:876-883. doi:10.3171/jns.2006.104.6.876

34. El-Shehaby AM, Reda WA, Tawadros SR, Abdel Karim KM (2012) Low-dose Gamma Knife surgery for nonfunctioning pituitary adenomas. J Neurosurg 117 Suppl:84-88. doi:10.3171/2012.6.GKS12986

35. Jagannathan J, Sheehan JP, Pouratian N, Laws ER, Steiner L, Vance ML (2007) Gamma Knife surgery for Cushing's disease. J Neurosurg 106:980-987. doi:10.3171/jns.2007.106.6.980

36. Leber KA, Bergloff J, Pendl G (1998) Dose-response tolerance of the visual pathways and cranial nerves of the cavernous sinus to stereotactic radiosurgery. J Neurosurg 88:43-50. doi:10.3171/jns.1998.88.1.0043

37. Leavitt JA, Stafford SL, Link MJ, Pollock BE (2013) Long-term evaluation of radiation-induced optic neuropathy after single-fraction stereotactic radiosurgery. Int J Radiat Oncol Biol Phys 87:524-527.

doi:10.1016/j.ijrobp.2013.06.2047

38. Pollock BE, Link MJ, Leavitt JA, Stafford SL (2014) Dose-volume analysis of radiation-induced optic neuropathy after single-fraction stereotactic radiosurgery. Neurosurgery 75:456-460. doi:10.1227/NEU.0000000000000457 discussion 460

\section{Tables}


Table 1

Comparison of demographic features and dosimetric parameters between groups with treatment success and failure after Gamma knife surgery

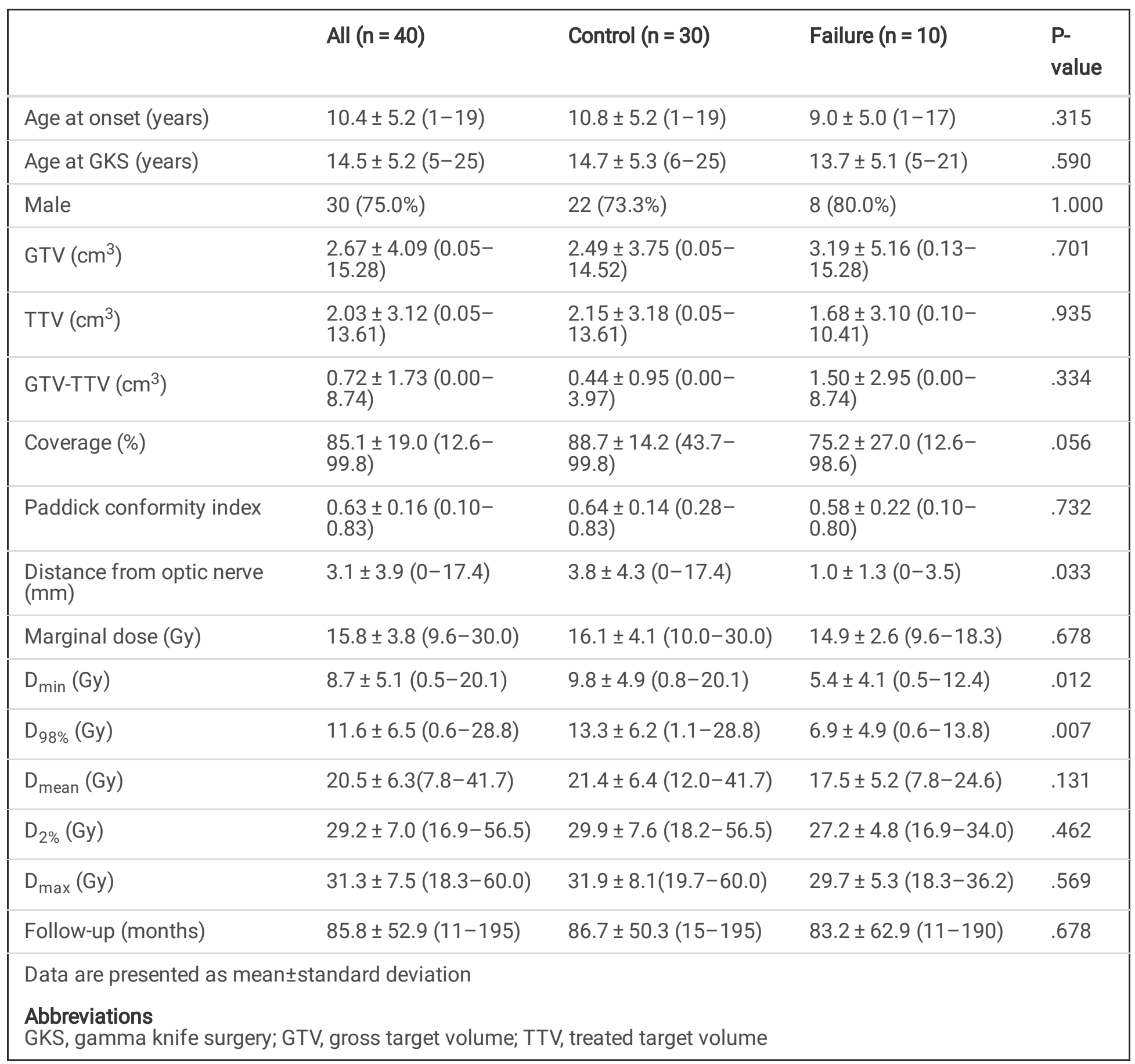


Table 2

Demographic features and dosimetric parameters in different diagnostic groups

\begin{tabular}{|c|c|c|c|c|c|c|}
\hline & $\begin{array}{l}\text { Craniopharyngioma } \\
(n=22)\end{array}$ & $\begin{array}{l}\text { Functioning } \\
\text { pituitary } \\
\text { adenoma } \\
(n=6)\end{array}$ & $\begin{array}{l}\text { Non- } \\
\text { functioning } \\
\text { pituitary } \\
\text { adenoma } \\
(n=6)\end{array}$ & $\begin{array}{l}\text { Chordoma, } \\
\text { chondrosarcoma } \\
(n=3)\end{array}$ & $\begin{array}{l}\text { Pilocytic } \\
\text { astrocytoma } \\
(n=2)\end{array}$ & $\begin{array}{l}\text { Anaplastic } \\
\text { astrocytoma } \\
(n=1)\end{array}$ \\
\hline $\begin{array}{l}\text { Age at } \\
\text { onset } \\
\text { (years) }\end{array}$ & $8.0 \pm 3.9$ & $14.8 \pm 3.1$ & $16.2 \pm 2.1$ & $12.7 \pm 4.2$ & $6.5 \pm 7.8$ & 3 \\
\hline $\begin{array}{l}\text { Age at } \\
\text { GKS } \\
\text { (years) }\end{array}$ & $13.3 \pm 5.4$ & $18.3 \pm 2.3$ & $17.3 \pm 1.5$ & $13.3 \pm 4.6$ & $13.0 \pm 9.9$ & 5 \\
\hline Male & $15(68.2 \%)$ & $5(83.3 \%)$ & 5 (83.3\%) & $3(100 \%)$ & $1(50 \%)$ & $1(100 \%)$ \\
\hline $\mathrm{GTV}\left(\mathrm{cm}^{3}\right)$ & $0.74 \pm 1.05$ & $6.05 \pm 6.32$ & $7.01 \pm 5.60$ & $2.83 \pm 0.63$ & $1.05 \pm 1.05$ & 1.505 \\
\hline $\operatorname{TTV}\left(\mathrm{cm}^{3}\right)$ & $0.68 \pm 1.00$ & $3.23 \pm 4.16$ & $5.85 \pm 4.74$ & $2.95 \pm 0.29$ & $0.54 \pm 0.35$ & 1.23 \\
\hline $\begin{array}{l}\text { GTV-TTV } \\
\left(\mathrm{cm}^{3}\right)\end{array}$ & $0.09 \pm 0.19$ & $2.81 \pm 3.51$ & $1.15 \pm 1.49$ & $0.20 \pm 0.16$ & $0.51 \pm 0.70$ & 0.27 \\
\hline $\begin{array}{l}\text { Coverage } \\
(\%)\end{array}$ & $90.1 \pm 14.3$ & $69.0 \pm 30.2$ & $86.5 \pm 10.7$ & $94.0 \pm 4.31$ & 70.3 & 82 \\
\hline $\begin{array}{l}\text { Paddick } \\
\text { conformity } \\
\text { index }\end{array}$ & $0.64 \pm 0.14$ & $0.52 \pm 0.26$ & $0.71 \pm 0.07$ & $0.68 \pm 0.04$ & $0.51 \pm 0.31$ & 0.69 \\
\hline $\begin{array}{l}\text { Distance } \\
\text { from optic } \\
\text { nerve } \\
(\mathrm{mm})\end{array}$ & $3.2 \pm 4.1$ & $0.97 \pm 1.10$ & $2.48 \pm 2.50$ & $7.37 \pm 5.24$ & $5.45 \pm 7.71$ & 0 \\
\hline $\begin{array}{l}\text { Marginal } \\
\text { dose (Gy) }\end{array}$ & $15.3 \pm 2.9$ & $19.6 \pm 6.8$ & $\begin{array}{l}13.64= \pm \\
1.5\end{array}$ & $16.5 \pm 0.9$ & $16.0 \pm 2.8$ & 15 \\
\hline $\mathrm{D}_{\min }(\mathrm{Gy})$ & $9.6 \pm 4.8$ & $7.1 \pm 7.5$ & $7.2 \pm 3.2$ & $10.5 \pm 2.1$ & $8.0 \pm 10.1$ & 4.2 \\
\hline $\mathrm{D}_{98 \%}(\mathrm{~Gy})$ & $12.5 \pm 6.0$ & $10.1 \pm 10.6$ & $10.5 \pm 3.5$ & $14.6+2.9$ & $9.3 \pm 11.7$ & 7.9 \\
\hline $\mathrm{D}_{\text {mean }}(\mathrm{Gy})$ & $20.7 \pm 5.5$ & $22.1 \pm 12.1$ & $17.8 \pm 2.1$ & $22.7 \pm 2.3$ & $18.5 \pm 9.1$ & 18.7 \\
\hline$D_{2 \%}(G y)$ & $28.9 \pm 6.2$ & $33.9 \pm 12.3$ & $25.2 \pm 2.8$ & $30.1 \pm 1.5$ & $29.8 \pm 4.5$ & 27.75 \\
\hline$D_{\max }(G y)$ & $30.5 \pm 6.6$ & $37.8 \pm 12.7$ & $27.2 \pm 3.2$ & $33.1 \pm 1.8$ & $32.1 \pm 5.7$ & 29.9 \\
\hline Recurrence & 7 (31.8\%) & 2 (33.3\%) & $0(0 \%)$ & 0 & 0 & $1(100 \%)$ \\
\hline $\begin{array}{l}\text { Time to } \\
\text { treatment } \\
\text { failure } \\
\text { (months) }\end{array}$ & $34.29+28.45$ & $\begin{array}{l}13.75 \pm \\
14.73\end{array}$ & - & - & - & 5 \\
\hline $\begin{array}{l}\text { Follow-up } \\
\text { (months) }\end{array}$ & $92.9 \pm 56.5$ & $\begin{array}{l}58.67 \pm \\
47.74\end{array}$ & $\begin{array}{l}95.67 \pm \\
34.98\end{array}$ & $74.33 \pm 74.65$ & $113 \pm 7.07$ & 13 \\
\hline
\end{tabular}




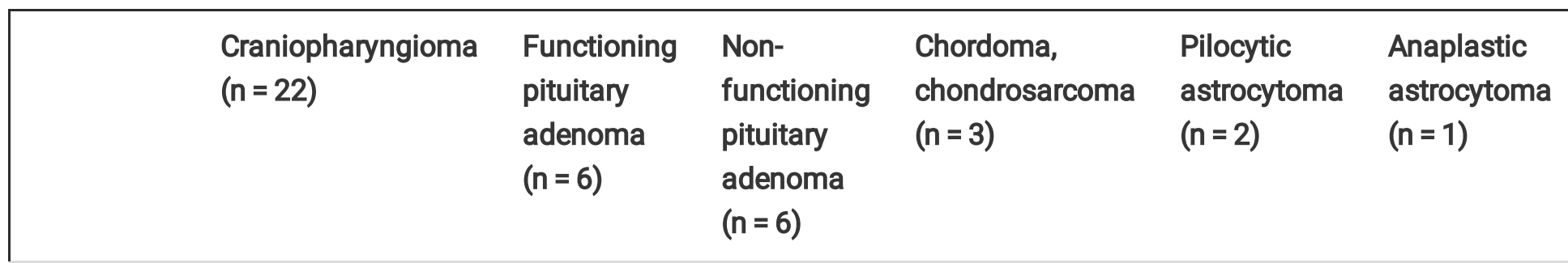

Data are presented as mean \pm standard deviation

Abbreviations: GKS, gamma knife surgery; GTV, gross target volume; TTV, treated target volume 
Table 3

Univariate and multivariate Cox proportional hazard regression analyses of factors associated with treatment failure in the entire cohort

\begin{tabular}{|c|c|c|c|c|c|c|}
\hline \multirow[t]{2}{*}{ Variable } & \multicolumn{3}{|c|}{ Univariate analysis } & \multicolumn{3}{|c|}{ Multivariate analysis } \\
\hline & $\begin{array}{l}\text { Unadjusted } \\
\text { HR }\end{array}$ & $95 \% \mathrm{Cl}$ & $\begin{array}{l}\mathrm{p}- \\
\text { value }\end{array}$ & $\begin{array}{l}\text { Unadjusted } \\
\text { HR }\end{array}$ & $95 \% \mathrm{Cl}$ & $\begin{array}{l}\mathrm{p}- \\
\text { value }\end{array}$ \\
\hline Age at onset (years) & 0.953 & $\begin{array}{l}0.843- \\
1.078\end{array}$ & .446 & & & \\
\hline Age at GKS (years) & 0.970 & $\begin{array}{l}0.861- \\
1.091\end{array}$ & .608 & & & \\
\hline Male & 0.738 & $\begin{array}{l}0.157- \\
3.482\end{array}$ & .702 & & & \\
\hline $\mathrm{GTV}\left(\mathrm{cm}^{3}\right)$ & 1.042 & $\begin{array}{l}0.911- \\
1.193\end{array}$ & .548 & & & \\
\hline $\operatorname{TTV}\left(\mathrm{cm}^{3}\right)$ & 0.960 & $\begin{array}{l}0.762- \\
1.208\end{array}$ & .726 & & & \\
\hline GTV-TTV $\left(\mathrm{cm}^{3}\right)$ & 1.443 & $\begin{array}{l}1.072- \\
1.942\end{array}$ & .016 & & & \\
\hline Coverage (\%) & 0.965 & $\begin{array}{l}0.938- \\
0.993\end{array}$ & .016 & & & \\
\hline Paddick conformity index & 0.079 & $\begin{array}{l}0.002- \\
3.483\end{array}$ & .189 & & & \\
\hline $\begin{array}{l}\text { Distance from optic nerve } \\
(\mathrm{mm})\end{array}$ & 0.683 & $\begin{array}{l}0.448- \\
1.043\end{array}$ & .078 & & & \\
\hline Marginal dose (Gy) & 0.931 & $\begin{array}{l}0.761- \\
1.139\end{array}$ & .489 & & & \\
\hline $\mathrm{D}_{\min }(\mathrm{Gy})$ & 0.831 & $\begin{array}{l}0.715- \\
0.967\end{array}$ & .017 & & & \\
\hline $\mathrm{D}_{98 \%}(\mathrm{~Gy})$ & 0.846 & $\begin{array}{l}0.749- \\
0.956\end{array}$ & .007 & 0.846 & $\begin{array}{l}0.749- \\
0.956\end{array}$ & .007 \\
\hline $\mathrm{D}_{\text {mean }}(\mathrm{Gy})$ & 0.883 & $\begin{array}{l}0.770- \\
1.012\end{array}$ & .073 & & & \\
\hline$D_{2 \%}(G y)$ & 0.948 & $\begin{array}{l}0.850- \\
1.056\end{array}$ & .334 & & & \\
\hline $\mathrm{D}_{\max }(\mathrm{Gy})$ & 0.968 & $\begin{array}{l}0.879- \\
1.066\end{array}$ & .505 & & & \\
\hline
\end{tabular}

\section{Figures}




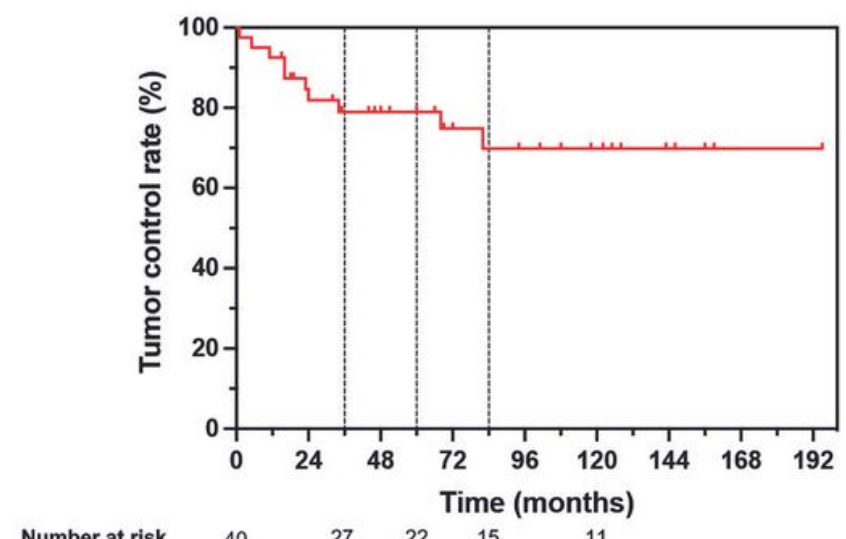

$\begin{array}{lllll}\text { Number at risk } & 40 & 27 & 22 & 15\end{array}$

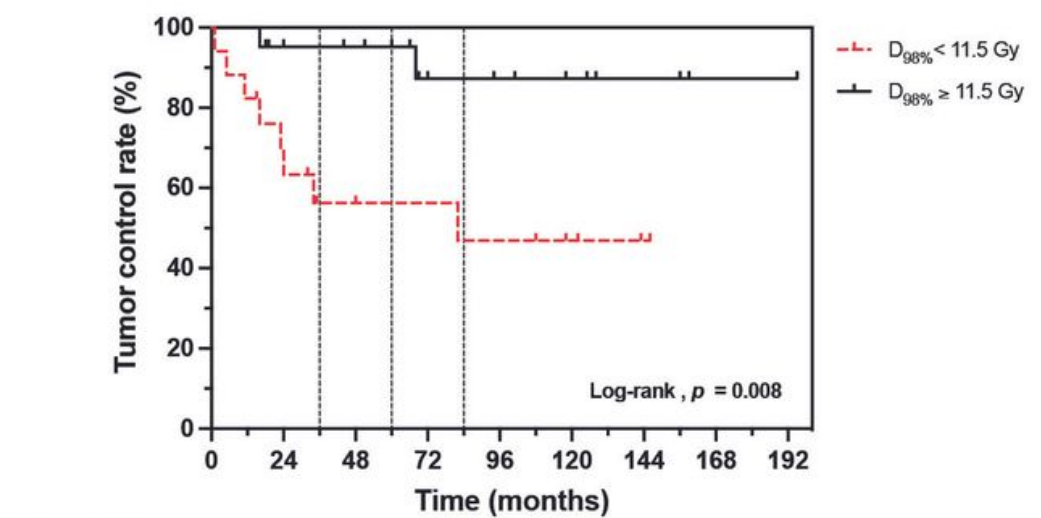

Number at risk

$D_{98 \%}<11.5$ Gy

$\mathrm{D}_{98 \%} \geq 11.5 \mathrm{~Gy}$

b

\section{Figure 1}

Comparison of the dosimetric parameters between treatment success and failure groups after Gamma knife surgery. The boxes represent the minimum to maximum values, with the lines indicating the median values. GTV, gross tumor volume; TTV, treated tumor volume

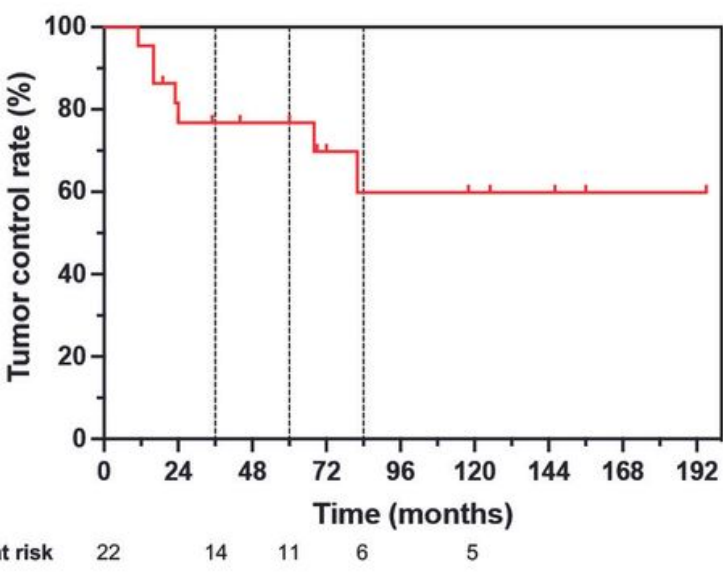

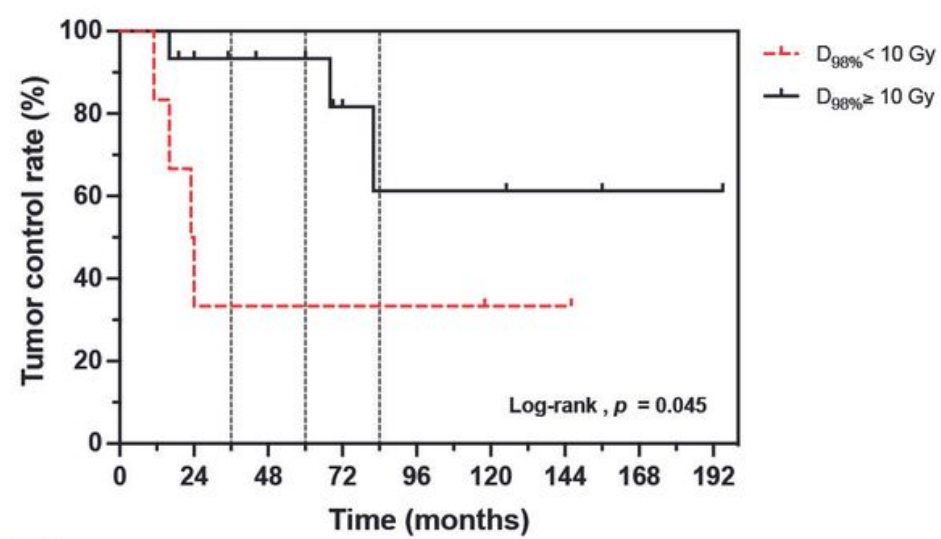

Number at risk

$D_{98 \%}<10$ Gy $\quad 6 \quad 3 \quad 3 \quad 3 \quad 3 \quad 2$

\section{Figure 2}

Kaplan-Meier curves depicting the tumor control rate of Gamma knife surgery for sellar and parasellar tumors. a) The tumor control rates in entire cohort. b) The group with $\mathrm{D} 98 \% \geq 11.5$ Gy showed a significantly better tumor control rate than the group with D98\% $<11.5 \mathrm{~Gy}$. 


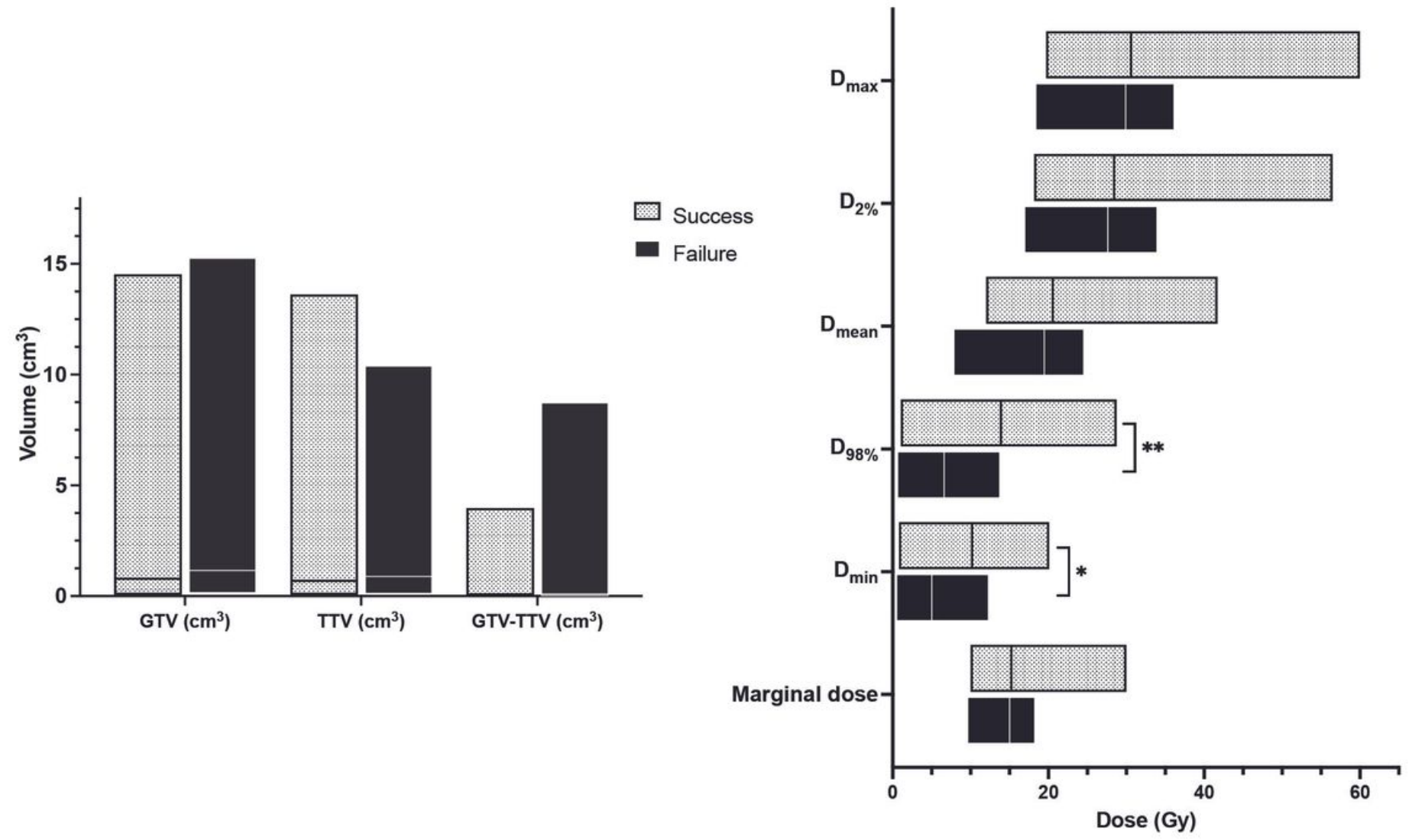

Figure 3

Kaplan-Meier curves depicting the tumor control rate of Gamma knife surgery for craniopharyngiomas. a) The overall tumor control rates $\mathrm{b}$ ) The group with $\mathrm{D} 98 \% \geq 10$ Gy showed a significantly better tumor control rate than the group with D98\% $<10$ Gy.

\section{Supplementary Files}

This is a list of supplementary files associated with this preprint. Click to download.

- SupplementalTable1.docx 